BNL-61990

Informal Report

\title{
MEASUREMENT OF HVAC SYSTEM PERFORMANCE AND LOCAL VENTILATION USING PASSIVE PERFLUOROCARBON TRACER TECHNOLOGY
}

\author{
Russell N. Dietz and Robert W. Goodrich \\ Environmental Chemistry Division \\ Department of Applied Science \\ Brookhaven National Laboratory \\ Upton, NY 11973-5000
}

June 1995

Prepared in part for the State University of New York, College of Technology

Farmingdale, NY 


\section{DISCLAIMER}

This report was prepared as an account of work sponsored by an agency of the United States Government. Neither the United States Government nor any agency thereof, nor any of their employees, make any warranty, express or implied, or assumes any legal liability or responsibility for the accuracy, completeness, or usefulness of any information, apparatus, product, or process disclosed, or represents that its use would not infringe privately owned rights. Reference herein to any specific commercial product, process, or service by trade name, trademark, manufacturer, or otherwise does not necessarily constitute or imply its endorsement, recommendation, or favoring by the United States Government or any agency thereof. The views and opinions of authors expressed herein do not necessarily state or reflect those of the United States Government or any agency thereof. 


\section{DISCLAIMER}

Portions of this document may be illegible in electronic image products. Images are produced from the best available original document. 


\section{INTRODUCTION}

In April of 1993, two (2) perfluorocarbon tracer (PFT) ventilation/indoor air quality assessment tests were performed in the Gleeson Hall building of the SUNY Farmingdale campus. The building was being modified, in part, as a result of significant occupant complaints of perceived poor air quality. Arrangements were made by Integrated Innovation Inc., in cooperation with SUNY Farmingdale, to invite Brookhaven to demonstrate the feasibility and utility of their passive BNL/AIMS (air infiltration measurement system) technique with a subsequent goal of determining if the SUNY education system wished to include the technology in the syllabus of their HVAC education program.

The four story $\left(22,000 \mathrm{ft}^{2} /\right.$ floor $)$ building had a basement first floor with air supplied normally by an HVAC system labelled as AC1. During this study, $\mathrm{ACl}$ was inoperational and the basement interior rooms (walls) were primarily gone; the other three floors were still being used for classes. It is possible that a sense of poor air quality may have been perceived by firstfloor occupants because they were working in the basement, but this issue could not be addressed.

The second floor (at ground level with 200-series room numbers) had two (2) lecture halls -- Rm 202 (handled by AC4) and Rm 204 (handled by AC5); the balance of the second floor interior rooms and corridors was split between two other air handling systems, AC2 for the west side of the building and AC3 for the east side (cf., Fig. 1). The remaining 3rd and 4th floors (cf., Figs. 2 and 3) were also split about evenly between $\mathrm{AC} 2$ and AC3. The perimeter rooms, equipped with wall units having their own outside air (OA) source plus centralized return air (RA) bypasses, were not included in this testing which was restricted to the basement floor (1st floor) and the four operating air handling systems, AC2 to AC5, during Test 1 and only AC2 to AC5 during Test 2.

Two types of tests were performed using the full suite of 5 PFT types available. The first test was designed to measure the infiltration, exfiltration, and air exchange between the $5 \mathrm{AC}$ zones above and the second test used the 5 th tracer, which had been in the basement, as a 
distributed source throughout the four other zones to act as a surrogate pollutant source -- such as $\mathrm{CO}_{2}$ from the breath of office personnel, teachers, and students.

This report provides final conclusions of both tests and suggestions regarding its usefulness in similar building ventilation and indoor air quality assessments.

\section{EXPERIMENTAL}

Details on the use of the BNL/AIMS technology 1 and the calculation of ventilation rates and their uncertainties 2 have been presented elsewhere. The number of PFT sources used in each zone (cf., Table 1) were tailored to expected ventilation rates and zone volumes in order to achieve primary tracer zonal concentrations of about 0.5 to 1.0 parts-per-trillion (ppt) which is equivalent to picoliters per liter $(\mathrm{pL} / \mathrm{L})$ or nanoliters per cubic meter $\left(\mathrm{nL} / \mathrm{m}^{3}\right)$.

Table 1

Number of PFT Sources and CATS Samplers Used

\begin{tabular}{|c|c|c|c|c|c|c|c|c|c|}
\hline \multirow{2}{*}{$\begin{array}{l}\text { Test } \\
\text { No. }\end{array}$} & \multirow[b]{2}{*}{ Period } & \multicolumn{3}{|c|}{ Zones } & \multicolumn{2}{|c|}{ PFT Sources } & \multicolumn{3}{|c|}{ Sampler Qty In: } \\
\hline & & No. & Location & Vol., $\mathrm{m}^{3}$ & Qty & Type & Room & Corr. & SA Grills \\
\hline \multirow[t]{5}{*}{1} & $4 / 7-9 / 93$ & 1 & 1st Floor & 8200 & 14 & $\overline{\mathrm{oPDCH}}$ & 5 & -- & $\overline{--}$ \\
\hline & & 2 & $\mathrm{AC} 2$ & 4580 & 3 & PMCP & 6 & 4 & -- \\
\hline & & 3 & $\mathrm{AC} 3$ & 5100 & 5 & $\mathrm{PMCH}$ & 8 & 1 & -- \\
\hline & & 4 & $\mathrm{AC} 4$ & 740 & 3 & pPDCH & 3 & -- & -- \\
\hline & & 5 & AC5 & 680 & 6 & PTCH & 3 & -- & -- \\
\hline \multirow[t]{5}{*}{2} & $4 / 9-12 / 93$ & 1 & $\mathrm{AC} 2$ & 4580 & 3 & PMCP & 6 & 4 & 3 \\
\hline & & 2 & $\mathrm{AC} 3$ & 5100 & 5 & $\mathrm{PMCH}$ & 8 & 1 & 3 \\
\hline & & 3 & $\mathrm{AC} 4$ & 740 & 3 & pPDCH & 3 & -- & 2 \\
\hline & & 4 & Rm 204 & 680 & 6 & PTCH & 3 & - & 2 \\
\hline & & All & (Pollutant & urrogate) & 14 & oPDCH & - & -- & -- \\
\hline
\end{tabular}

Test 1 was performed as a 5-zone study to assess the general ventilation performance of the building in its then current state prior to reconstruction of the layout of rooms and ventilation controls. The number of sources and samplers deployed is shown in Table 1. The first floor air handler $(\mathrm{AH}), \mathrm{ACl}$, was not operating because of the reconstruction, so the 14 PFT sources were 
distributed uniformly around that level; it would be expected that that floor's ACH (air change per hour) rate should be low both because the $\mathrm{AH}$ was not operating and the first floor was below grade (few air leakage locations).

The next three (3) zones, AC2 to AC4, were tagged by deploying the PFTs within a nylon stocking which was suspended in the appropriate return air (RA) duct locations, that is, after any exhaust air (EA) location but before the addition of any outside air (OA) so that source temperature would be accurately known. The last zone, Lecture Rm 204, handled by AC5, had the 6 PFT sources distributed uniformly throughout the room because initially (on 4/7/93) the $\mathrm{AH}$ was not running; it was operating on 4/9/93 when the Test 1 sampling was terminated. It was also operating throughout Test 2 , but the sources were left in their original locations.

During Test 1, samplers were deployed throughout numerous rooms of the five zones and also in the corridors of the 2 nd, 3 rd, and 4th floors. During Test 2, samplers were also deployed in the supply air (SA) grill in order the distinguish mechanical OA from natural infiltration directly into each of the four zones. However, mechanical outside air from the perimeter rooms would appear as natural infiltration in the tested zones, so this calculation was not performed.

\section{RESULTS}

\section{Ventilation Calculations}

The complete BNL-AIMS output sheets for the two tests are shown in the Appendix as Table A1 and A2. A general discussion of the output format shows, at the top of the sheet, the sampling period, the date the samplers were analyzed, and the date the results were computed. The next section, "Rates", gives the overall $\mathrm{ACH}$ for all zones tested followed by the individual zone results, starting on the left with zone number and name, the PFT source rate (nominal and corrected for number used and zone temperature), the exfiltration rate and standard deviation (SD), and the infiltration rate and SD (both in $\mathrm{m}^{3} / \mathrm{h}$ and in $\mathrm{h}-1$, that is, rate divided by zone volume).

Next are the zone-to-zone air exchange rates and their SDs. For example, 1-2 means the air flow from zone 1 ( 1 st floor in Test 1) to zone 2 (AC2) was $805 \pm 176 \mathrm{~m}^{3} / \mathrm{h}$; flow in the reverse 
direction (2-1) was $837 \pm 171 \mathrm{~m}^{3} / \mathrm{h}$ or about equal air exchange in both directions. Zones which had little air exchange were AC4 to AC5 (4-5 in Test 1) and reverse $\left(<100 \mathrm{~m}^{3} / \mathrm{h}\right)$; those with large air exchange were AC2 to AC3 (2-3 in Test 1) and reverse at 3,000 to $4,000 \mathrm{~m}^{3} / \mathrm{h}$--quite natural since these AHs conditioned space that was open to shared corridors on each of these floors. Lastly, are the Total Flow In or Out rates which is the sum of all flows from outside air and from all other zones or to outside and to all other zones.

The next section, "Analysis", gives, in the upper part for each zone, its volume and the PFT source type deployed followed by the average PFT concentration and SD for the primary zone tracers found in each zone. Note that the highest PFT concentration should occur in the zone in which that PFT was deployed, that is, the diagonal locations in the average tracer concentration matrix. On the second page are the concentrations of each PFT found on each CATS sampler tube. When the word "DELETED" appears, it means those values were not included in the averages above. For example, location $\mathrm{M} 7$ on the first floor, corridors $\mathrm{C} 46$ and $\mathrm{C} 48$ on the 4 th floor, etc., were deemed not to be representative of the concentrations found elsewhere in those zones and were excluded from the averages. In Test 2 (Table A2), samplers deployed in SA grills were also deleted.

The last section, "Notes", contains among other items, the overall normalized concentration matrix condition number $(0.502$ in Test $1 ; 0.543$ in Test 2$)$ and the zonal condition number (near unity). When the former is less than 2 , the test is quite good; these tests were exceptional. It should be noted that the rates shown in the upper section are computed from the source rates and average tracer concentrations as follows using matrix notation:

$$
\mathbf{R}=\mathbf{C}^{-1} \mathbf{S}
$$

This solution and the matrix solution for the standard deviations have been presented elsewhere. 2

\section{Indoor Air Quality (IAQ) Assessment}

As described above, the PFT technology can completely characterize the air flows in a multizone building. But the same technology, when an additional PFT is used as a surrogate 
pollutant source throughout various rooms of the same building, can be used to calculate an apparent local $\mathrm{ACH}$ and local air quality.

For this school building, the major air quality issue would be local $\mathrm{CO}_{2}$ levels generated from the breathing of students, teachers, and administrative personnel as non-uniformly distributed $\mathrm{CO}_{2}$ sources. A sedentary adult will emit about $19 \mathrm{~L} / \mathrm{h}$ of $\mathrm{CO}_{2}$, an active adult $24 \mathrm{~L} / \mathrm{h}$, and active child $14 \mathrm{~L} / \mathrm{h}$. For the evaluation here, the sedentary adult rate $(19,000 \mathrm{~mL} / \mathrm{h})$ was used. As indicated in Table 1, $14 \mathrm{oPDCH}$ sources were deployed in various rooms in all four zones of Test 2, one in each of 12 rooms and 2 in the 13th -- Room 204, served by AC5.

In each of these rooms, there is a local rate of ventilation based on air exchange between the room and both supply air (SA) and adjacent room(s) which is equal to the vapor source strength in the room divided by the change in concentration of the vapor in the room due to that source, namely,

$$
\mathrm{R}_{\ell}=\frac{\mathrm{S}_{\ell}}{\Delta \mathrm{C}_{\ell}}
$$

where the local vapor can be from either the oPDCH PFT source deployed in the room or the expected $\mathrm{CO}_{2}$ source (the number of people in that room times the adult $\mathrm{CO}_{2}$ generation rate).

The relationship between the change in concentration of ocPDCH (the measured isomer of the deployed oPDCH source) and its local source strength and that between the change in the local pollutant concentration (e.g., $\mathrm{CO}_{2}$ ) and its local source strength (the number of people in the room times $\mathrm{S}_{\mathrm{CO}_{2}}$ ) is a function of the time required to ventilate a local area or, in terms of the local ventilation rate above,

$$
\mathrm{R}_{\ell}=\frac{\mathrm{S}_{\ell}^{\mathrm{oc}}}{\mathrm{C}_{\mathrm{R}}^{\mathrm{oc}}-\overline{\Delta \mathrm{C}}_{\mathrm{Z}}^{\mathrm{oc}}}=\frac{\mathrm{nS}_{\mathrm{CO}_{2}}}{\mathrm{C}_{\mathrm{R}}^{\mathrm{CO}_{2}}-360-\overline{\Delta C}_{\mathrm{Z}} \mathrm{CO}_{2}}
$$

where $R_{\ell}$ is the local ventilation rate $\left(\mathrm{m}^{3} / \mathrm{h}\right) ; S_{\ell}^{O C}$ is the local ocPDCH surrogate pollutant emission rate $(\mathrm{nL} / \mathrm{h}) ; \mathrm{nS}_{\mathrm{CO}_{2}}$ is the adult $\mathrm{CO}_{2}$ emission rate $(\mathrm{n} \times 19,000 \mathrm{~mL} / \mathrm{h})$ for " $\mathrm{n}$ " people present; $C_{R}$ and $\overline{\Delta C}_{Z}$ are the respective local room and incremental zonal average concentrations ( $\mathrm{nL} / \mathrm{m}^{3}$ for ocPDCH and $\mathrm{mL} / \mathrm{m}^{3}$, i.e., $\mathrm{ppm}$, for $\mathrm{CO}_{2}$ ); and 360 is the ambient $\mathrm{CO}_{2}$ concentration (ppm). The right denominator in Eq. 2 is the incremental or change in local room $\mathrm{CO}_{2}$ concentration, that is 


$$
\Delta \mathrm{C}_{\ell}^{\mathrm{CO}_{2}}=\mathrm{C}_{\mathrm{R}}^{\mathrm{CO}_{2}}-360-\overline{\Delta \mathrm{C}}_{\mathrm{Z}}^{\mathrm{CO}_{2}}=\frac{\mathrm{nS}_{\mathrm{CO}_{2}}}{\mathrm{~S}_{\mathrm{oc}}}\left(\mathrm{C}_{\mathrm{R}}^{\mathrm{oc}}-\overline{\Delta \mathrm{C}}_{\mathrm{Z}}^{\mathrm{oc}}\right)
$$

The left side of Eq. 2 can be used to compute the local ventilation rate in rooms tagged with the oPDCH source $\left(\mathrm{S}_{\mathrm{oc}}\right.$ is known and $\mathrm{C}_{\mathrm{R}}^{\mathrm{oc}}$ is locally measured) if the zonal average ocPDCH concentration, $\overline{\Delta C}_{\mathrm{z}}^{\mathrm{oc}}$, can be determined. Table 2 provides the data used to calculate the room ocPDCH concentration which would have been present from zonal SA only assuming that the ratio of Grill/Room concentrations for the PFT used in the zone would have the same ratio for other PFTs (including the pollutant surrogate) supplied via the grill. Note that PMCH was used for zone 4 (AC5, Room 204) because the PTCH used in that zone was deployed in the room rather than via the SA ducting. The last column, predicted ocPDCH change in concentration, will be described shortly.

Table 2

Estimated Zonal Surrogate Pollutant (ocPDCH) Concentration

\begin{tabular}{|c|c|c|c|c|c|c|c|c|}
\hline \multirow[b]{2}{*}{ Zone } & \multirow[b]{2}{*}{$\mathrm{AH}$} & \multicolumn{4}{|c|}{ Zone PFT Conc., $\mathrm{nL} / \mathrm{m}^{3}$} & \multicolumn{3}{|c|}{$\begin{array}{c}\text { "Surrogate" } \overline{\Delta C}_{z}^{o c} \\
\text { ocPDCH Conc. Change, } \mathrm{nL} / \mathrm{m}^{3}\end{array}$} \\
\hline & & PFT & & Grill & Room & Grill & Room & Predicted \\
\hline 1 & $\mathrm{AC} 2$ & PMCP & 0.5 & \pm 0.0 & $0.37 \pm 0$ & \pm 0.03 & $0.13 \pm 0.02$ & 0.174 \\
\hline 2 & $\mathrm{AC} 3$ & $\mathrm{PMCH}$ & 0.56 & \pm 0 & $0.56 \pm 0$ & $2 \pm 1$ & $=0.02$ & 0.222 \\
\hline 3 & $\mathrm{AC} 4$ & $\mathrm{CH}$ & 0.7 & & $0.65 \pm 0$ & $23 \pm 0.00$ & \pm 0.01 & 0.217 \\
\hline 4 & AC5 & $\mathrm{PMCH}$ & 0.050 & \pm 0.001 & $0.044 \pm 0.001$ & $0.10 \pm 0.01$ & $0.09 \pm 0.01$ & 0.155 \\
\hline
\end{tabular}

The right side of Eq. 3 can be used to compute the expected change in room $\mathrm{CO}_{2}$ concentration if the zonal $\mathrm{CO}_{2}$ concentration change is known; the latter is the average expected change in $\mathrm{CO}_{2}$ concentration in each $\mathrm{AH}$ zone based on the assumption that the $\mathrm{CO}_{2}$ emitted from all the people in that zone was released at the same location in the RA duct where the zonal PFT sources were deployed. The PFT concentration matrix from Table A2 in the Appendix is repeated in Table 3 below along with the respective PFT source rates. An estimate of the number of people present in each of the various rooms comprising the entire zones is also given in Table 3, from which the estimated total $\mathrm{CO}_{2}$ source strength per zone is given. Then, for each zonal column, the incremental $\Delta \mathrm{CO}_{2}$ concentration, that is, concentration above ambient for the entire zone, is calculated by 
Table 3

Estimated Zonal Incremental $\mathrm{CO}_{2}$ Concentrations

Est.

\begin{tabular}{|c|c|c|c|c|c|c|c|c|c|c|c|c|c|}
\hline \multirow[b]{2}{*}{ Zone } & \multirow[b]{2}{*}{$\underline{\mathrm{AH}}$} & \multirow{2}{*}{$\begin{array}{l}\text { SPFT, } \\
\mathrm{nL} / \mathrm{h} \\
\end{array}$} & \multicolumn{4}{|c|}{$C_{\text {PFT }}, n L / m^{3}$} & \multirow{2}{*}{$\begin{array}{c}\text { No. of } \\
\text { People (n) } \\
\end{array}$} & \multirow{2}{*}{$\begin{array}{c}\mathrm{nSCO}_{2}{ }^{1} \\
10^{6} \mathrm{~mL} / \mathrm{h} \\
\end{array}$} & \multicolumn{5}{|c|}{$\Delta \mathrm{C}_{\mathrm{CO}_{2}}, \mathrm{~mL} / \mathrm{m}^{3}$} \\
\hline & & & 1 & 2 & 3 & 4 & & & 1 & 2 & 3 & 4 & $\overline{\Delta C}_{\mathrm{Z}} \mathrm{CO}_{2}$ \\
\hline 1 & $\mathrm{AC} 2$ & 5773 & 0.372 & 0.135 & 0.033 & 0.002 & 77 & 1.46 & 94 & 46 & 27 & 1 & 168 \\
\hline 2 & AC3 & 6667 & 0.089 & 0.559 & 0.028 & 0.012 & 120 & 2.28 & 23 & 191 & 23 & 9 & 246 \\
\hline 3 & $\mathrm{AC} 4$ & 1389 & 0.075 & 0.063 & 0.653 & 0.004 & 60 & 1.14 & 19 & 22 & 536 & 3 & 580 \\
\hline 4 & AC5 & 1541 & 0.028 & 0.049 & 0.014 & 0.285 & 60 & 1.14 & 7 & 17 & 11 & 211 & 246 \\
\hline
\end{tabular}

T $\mathrm{S}_{\mathrm{CO}_{2}}=19,000 \mathrm{~mL} / \mathrm{h} \cdot$ person

$$
\Delta \mathrm{C}_{\mathrm{CO}_{2}}=\mathrm{C}_{\mathrm{PFT}} \frac{\mathrm{nS}_{\mathrm{CO}_{2}}}{\mathrm{~S}_{\mathrm{PFT}}}
$$

and summing over all four $\mathrm{CO}_{2}$ sources strengths gives the total zonal incremental or change in $\mathrm{CO}_{2}$ concentration in the last column of Table 3.

This same procedure can be used to estimate or predict the zonal ocPDCH concentration. Using the same PFT concentration and source matrices from Table 3, Eq. 4 (but for ocPDCH) was used to calculate the predicted incremental zonal ocPDCH concentration as shown in Table $3 \mathrm{a}$ below and also listed in Table 2. It can be seen in that table that the predicted values agree very closely with the values measured in the SA grills for all but AC5. Because there were so few measured values, the predicted zonal ocPDCH incremental concentrations were the ones used in Table 4 along with other pertinent room information. Substitution into Eqs. 2 and 3 gave the room's local ventilation rate, $\mathrm{R}_{\ell}\left(\mathrm{m}^{3} / \mathrm{h}\right)$, apparent $\mathrm{ACH}\left(\mathrm{h}^{-1}\right)$, and the local incremental and

Table $3 \mathrm{a}$

Predicted "Surrogate" Pollutant (ocPDCH) Concentration

\begin{tabular}{|c|c|c|c|c|c|c|c|}
\hline \multirow[b]{2}{*}{ Zone } & \multirow{2}{*}{$\begin{array}{c}\text { No. of ocPDCH } \\
\text { Sources (n) }\end{array}$} & \multirow{2}{*}{$\begin{array}{l}\mathrm{nS}_{\mathrm{oc}} \\
\mathrm{nL} / \mathrm{h}\end{array}$} & \multicolumn{5}{|c|}{ "Surrogate" ocPDCH Conc., $n L / m^{3}\left(\Delta C_{\alpha c}\right)$} \\
\hline & & & 1 & 2 & 3 & 4 & Predicted \\
\hline 1 & 5 & 1856 & 0.120 & 0.044 & 0.009 & 0.001 & 0.174 \\
\hline 2 & 6 & 2157 & 0.029 & 0.181 & 0.007 & 0.005 & 0.222 \\
\hline 3 & 1 & 363.4 & 0.024 & 0.020 & 0.171 & 0.002 & 0.217 \\
\hline 4 & 2 & 680.7 & 0.009 & 0.016 & 0.004 & 0.126 & 0.155 \\
\hline
\end{tabular}


Table 4

Estimated Local Ventilation and Room $\mathrm{CO}_{2}$ Concentrations

\begin{tabular}{|c|c|c|c|c|c|c|c|c|c|c|c|c|c|c|c|}
\hline & Room & Vol., & $\begin{array}{c}\text { No. of } \\
\text { SA }\end{array}$ & $S_{\text {oc }}$ & $\mathrm{C}_{\mathrm{R}}^{\mathrm{oc}}$ & $\overline{\Delta C}_{z}^{o c}$ & $\mathrm{R}_{\ell}$ & $\begin{array}{l}\text { App. } \\
\text { ACH, }\end{array}$ & $\begin{array}{l}\text { No. of } \\
\text { People }\end{array}$ & $\mathrm{nS}_{\mathrm{CO}_{2}}$ & & $\begin{array}{r}\mathrm{PI} \\
\mathrm{CO}_{2} \\
\end{array}$ & $\begin{array}{l}\text { edicted } \\
\text { Eonc., ppm }\end{array}$ & & $\mathrm{R}_{\ell} /$ Grill, \\
\hline $\mathrm{AH}$ & No. & $\mathrm{m}^{3}$ & Grills & $\mathrm{nL} / \mathrm{h}$ & $\mathrm{nL} / \mathrm{m}^{3}$ & $\mathrm{~nL} / \mathrm{m}^{3}$ & $\mathrm{~m}^{3} / \mathrm{h}$ & $\mathrm{h}^{-1}$ & (n) & $10^{3} \mathrm{~mL} / \mathrm{h}$ & $\overline{\Delta \mathrm{C}}_{\mathrm{z}}$ & $\Delta \mathrm{C}_{\text {local }}$ & $\Delta \mathrm{C}_{\mathrm{R}} / \mathrm{p}_{\text {person }} 1$ & $\mathrm{C}_{\mathrm{R}}$ & $\mathrm{m}^{3} / \mathrm{h}$ \\
\hline $\mathrm{AC} 2$ & $444 \mathrm{~A}$ & 50 & 1 & 371 & 1.257 & 0.174 & 343 & 6.9 & 1 & 19 & 168 & 55 & 57 & 583 & 340 \\
\hline$"$ & 341 & 124 & 1 & 371 & 0.614 & 0.174 & 844 & 6.8 & 2 & 38 & 168 & 45 & 25 & 573 & 840 \\
\hline$"$ & 342 & 272 & 2 & 371 & 0.608 & 0.174 & 855 & 3.1 & 8 & 152 & 168 & 178 & 24 & 706 & 430 \\
\hline$"$ & $208 \mathrm{~A}$ & 376 & 9 & 371 & 0.182 & 0.174 & $>40,000$ & $>100$ & 20 & 380 & 168 & 8 & 2.6 & 536 & -- \\
\hline$"$ & $208 \mathrm{C}$ & 268 & 8 & 371 & 0.200 & 0.174 & 14,300 & 53 & 18 & 342 & 168 & 24 & 3.5 & 552 & 1,800 \\
\hline $\mathrm{AC} 3$ & 419 & 217 & 3 & 360 & 0.395 & 0.222 & 2,078 & 9.6 & 7 & 133 & 246 & 64 & 11.2 & 670 & 690 \\
\hline$"$ & 421 & 258 & 2 & 360 & 0.375 & 0.222 & 2,350 & 9.1 & 8 & 152 & 246 & 65 & 10.2 & 671 & 1,200 \\
\hline$"$ & 323 & 158 & 4 & 360 & 0.546 & 0.222 & 1,110 & 7.0 & 20 & 380 & 246 & 342 & 19 & 948 & 280 \\
\hline$"$ & 339 & 382 & 3 & 360 & 0.653 & 0.222 & 834 & 2.2 & 15 & 285 & 246 & 342 & 25 & 948 & 280 \\
\hline$"$ & $209 \mathrm{~B}$ & 118 & 2 & 360 & 1.146 & 0.222 & 389 & 3.3 & 2 & 38 & 246 & 98 & 51 & 704 & 190 \\
\hline$"$ & 213 & 76 & 2 & 360 & 0.782 & 0.222 & 642 & 8.4 & 10 & 190 & 246 & 296 & 32 & 902 & 320 \\
\hline $\mathrm{AC} 4$ & 202 & 740 & $6+$ & 363 & 0.237 & 0.217 & 18,170 & 24 & 60 & 1,140 & 580 & 63 & 10.7 & 1,003 & 3,000 \\
\hline AC5 & 204 & 680 & $6+$ & 681 & $\begin{array}{l}0.17- \\
0.23\end{array}$ & 0.155 & $\begin{array}{c}9,000- \\
45,000\end{array}$ & $13-66$ & 60 & 1,140 & 246 & $25-125$ & $4.5-6.2$ & $\begin{array}{l}630- \\
730\end{array}$ & $\begin{array}{l}1,500- \\
7,500\end{array}$ \\
\hline
\end{tabular}


room $\mathrm{CO}_{2}$ concentrations (ppm). Thus, any room $\mathrm{CO}_{2}$ concentration is comprised of the ambient background concentration, the incremental zonal concentration, and a local incremental concentration from a local source, that is,

$$
\mathrm{C}_{\mathrm{R}}=360+{\overline{\Delta \mathrm{C}_{\mathrm{z}}}}+\Delta \mathrm{C}_{\ell}
$$

Lastly, the expected change in the $\mathrm{CO}_{2}$ concentration per person in an individual room is given by

$$
\Delta \mathrm{C}_{\mathrm{R}} / \text { person }=\frac{\overline{\Delta \mathrm{C}}_{\mathrm{z}}}{\mathrm{n}_{\mathrm{z}}}+\frac{\Delta \mathrm{C}_{\ell}}{\mathrm{n}_{\mathrm{R}}}
$$

where $n_{z}$ and $n_{R}$ are the number of people in the zone and room, respectively.

The five rooms tested on AC2 had ventilation rates per grill of about $300 \mathrm{~m}^{3} / \mathrm{h}$ in $3 \mathrm{rd}$ and 4th floor rooms and greater than $1,500 \mathrm{~m}^{3} / \mathrm{h}$ per grill in rooms $208 \mathrm{~A}$ and C. Rooms with 8 and 9 grills, having more occupants, still maintained low projected $\mathrm{CO}_{2}$ concentrations. The six rooms tested on AC3 also showed differences in apparent ventilation rates per grill--high on the 4th floor (with low estimated $\mathrm{CO}_{2}$ levels) and low (equal to the $\mathrm{AC} 2$ rates on the $3 \mathrm{rd}$ and 4 th floors) on the third and second floors (with high estimated $\mathrm{CO}_{2}$ levels). With an estimated 20 people in each of rooms $208 \mathrm{~A}$ and 323 , the estimated $\mathrm{CO}_{2}$ levels in the latter (with only $4 \mathrm{SA}$ grills versus 9 in the former) were nearly twice (948 ppm) those in the other room (536 ppm). The indoor projected $\mathrm{CO}_{2}$ concentration is seen to range from 536 to more than $1,000 \mathrm{ppm}$; more than 600 ppm of $\mathrm{CO}_{2}$ may indicate the presence of an uncomfortable condition. ${ }^{4}$

Experience from others' measurements of $\mathrm{CO}_{2}$ levels, ventilation rates, and perceived comfort in buildings will be reviewed in the next section together with an assessment of the results here to suggest areas which would need improvement in the settings of the air handling systems in Gleeson Hall. The appropriate steps for remedial action will be presented.

\section{DISCUSSION}

\section{Gleeson Hall Ventilation Tests}

A significant amount of air flow information in available in a BNL-AIMS test result as in Tables A1 and A.2 in the Appendix. The infiltration rate for each zone is the amount of fresh 
outside air being supplied to each and, as such, is one potential indication of the level of indoor air quality (IAQ). For ACHs less than $0.5 \mathrm{~h}^{-1}$, IAQ could be poor, especially if occupied by a number of people; for values greater than 1.5 to $2.0 \mathrm{~h}^{-1}$, the likelihood is that IAQ will be acceptable, provided the overall potential pollutant burden or source strength in each zone (including total occupants) is in accord with the ventilation rate and the local pollutant source strength (e.g., ozone from a copier or $\mathrm{CO}_{2}$ from the local occupants) is also balanced with the local ventilation, for example, an appropriate number of SA grills for the rooms expected occupancy level.

Table 5

Zonal Infiltration Rate, $\mathrm{ACH}, \mathrm{h}^{-1}$

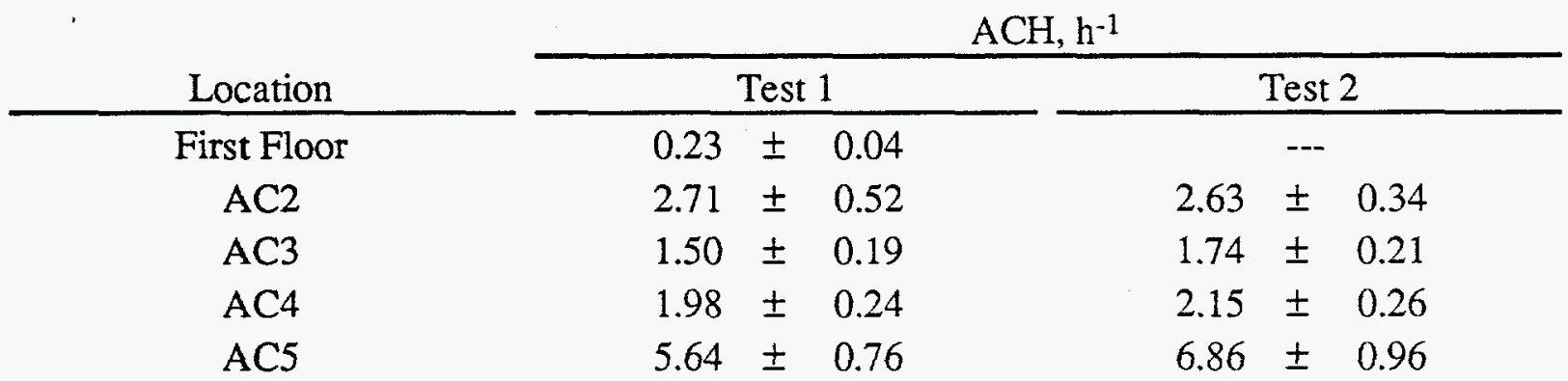

As shown in Table 5 above, with the exception of the first floor result (its mechanical system was not running) measured in Test 1 only, the four $\mathrm{AH}$ systems had $\mathrm{ACH}$ values exceeding $1.5 \mathrm{~h}^{-1}$; within their respective uncertainties, the results were also identical for both tests.

The west side of the building handled by AC2 might appear to have a higher-thannecessary rate of $2.7 \mathrm{~h}^{-1}$ when compared to the $1.6 \mathrm{~h}^{-1}$ rate found in the east side (AC3). This excess of $1.1 \mathrm{~h}^{-1}$ of ACH with an AC2 zone volume of $4580 \mathrm{~m}^{3}$ (see Table 1 or Analysis section in Table A1) corresponds to $5040 \mathrm{~m}^{3} / \mathrm{h}$ of potentially unnecessary conditioned air. Room 204 (controlled by AC5) also appeared to have a higher-than-necessary rate (there were no occupants over the weekend); if the average value of $6.2 \mathrm{~h}^{-1}$ was reduced to $1.6 \mathrm{~h}^{-1}$, the $4.6 \mathrm{~h}^{-1}$ savings for the $680-\mathrm{m}^{3}$ room (equivalent to $3130 \mathrm{~m}^{3} / \mathrm{h}$ excess) would also be significant. Another way to look at this is as follows: the total building volume of $11,100 \mathrm{~m}^{3}$ at $1.6 \mathrm{~h}^{-1}$ is equivalent to a 
fresh air rate of $17,800 \mathrm{~m}^{3} / \mathrm{h}$; the PFT-measured rate was $27,200 \mathrm{~m}^{3} / \mathrm{h}$ or an excess of $9,400 \mathrm{~m}^{3} / \mathrm{h}$.

The potential conditioned-space energy savings may be significant. As a rough rule-ofthumb, at a $0.5 \mathrm{~h}^{-1} \mathrm{ACH}$ rate, $25 \%$ of the heating or cooling requirement in a building is due to ventilation. It can be shown that based on this rule, reducing the whole building $\mathrm{ACH}$ from $2.5 \mathrm{~h}^{-1}$, the measured value in this case, down to $1.5 \mathrm{~h}^{-1}$, would save about $30 \%$ of the total energy expended at $1.5 \mathrm{~h}^{-1}$, certainly feasible when the building is not occupied, such as on weekends and at night. The question is: What $\mathrm{ACH}$ level is needed to assure adequate dilution of occupant-derived $\mathrm{CO}_{2}$ during the day.

\section{Ventilation and $\mathrm{CO}_{2}$ Levels in General}

The relationship between ventilation and indoor $\mathrm{CO}_{2}$ levels found by others due to occupants, fundamentally governed by Eq. 1, can be used to put several rules-of-thumb into perspective in order to determine what the ventilation rate and $\mathrm{CO}_{2}$ levels should be in Gleeson Hall. The following guidelines or observations have been promulgated along with ASHRAE requirements:

Buildings

Supply Air Rate (suggested):

$1.5 \mathrm{cfm} / \mathrm{ft}^{2}$ with $17 \%$ OA

ACHs (observed):

$1.0 \pm 0.5 \mathrm{~h}^{-1}$ of outside air (OA)

Occupancy (suggested):

$43 \mathrm{~m}^{3} /$ person or $14 \mathrm{~m}^{2} /$ person

Homes

Size:

$1800 \mathrm{ft}^{2}( \pm 40 \%)$

ACHs (observed):

$0.5 \pm 0.2 \mathrm{~h}^{-1}$ of $\mathrm{OA}$

Occupancy:

2 adults and 2 children

$\mathrm{CO}_{2}$ Rate

Adult:

$19 \mathrm{~L} / \mathrm{h}$

Child:

$12 \mathrm{~L} / \mathrm{h}$

ASHRAE $^{5}$

Minimum Ventilation:

Maximum $\mathrm{CO}_{2}$ :

$10 \mathrm{~L} / \mathrm{s} \cdot$ person

$1000 \mathrm{ppm}$ 
The expected $\mathrm{CO}_{2}$ level in a home can be calculated from Eq. $1(\Delta \mathrm{C}=\mathrm{S} / \mathrm{R})$ as follows:

$$
\begin{aligned}
\mathrm{R} & =1800 \mathrm{ft}^{2} \times 8 \mathrm{ft} \text { ceiling } \times 0.02831 \mathrm{~m}^{3} / \mathrm{ft}^{3} \times 0.5 \mathrm{~h}^{-1}(\mathrm{ACH}) \\
& =400 \mathrm{~m}^{3} \times 0.5 \mathrm{~h}^{-1} \\
& \approx 200 \mathrm{~m}^{3} / \mathrm{h} \text { or } 200,000 \mathrm{~L} / \mathrm{h} \\
\mathrm{S} & =19(2)+12(2)=62 \mathrm{~L} \mathrm{CO} / \mathrm{h} \\
\Delta \mathrm{C} & =\mathrm{S} / \mathrm{R}=62 \times 10^{6} / 200,000=310 \mathrm{ppm} \\
\mathrm{C} & =\Delta \mathrm{C}+360\left(\mathrm{CO}_{2} \text { ambient }\right)=670 \mathrm{ppm}
\end{aligned}
$$

The equivalent number of adults generating $62 \mathrm{~L} \mathrm{CO}_{2} / \mathrm{h}$ is $62 / 19$ or 3.26 persons for an occupancy volume of $400 \mathrm{~m}^{3} / 3.26$ persons or $123 \mathrm{~m}^{3} /$ person or about 3 times the occupancy volume in a commercial building ( $43 \mathrm{~m}^{3} /$ person).

The expected $\mathrm{CO}_{2}$ level in a building can also be estimated from the information above:

$$
\begin{aligned}
\text { Supply Air R/V } & =1.5 \mathrm{ft}^{3} / \mathrm{min} \cdot \mathrm{ft}^{2} \times 60 \mathrm{~min} / \mathrm{h} / 8.7 \mathrm{ft} \text { ceiling } \\
& =10.3 \mathrm{~h}^{-1} \\
\text { Outside Air R/V } & =17 \% \text { of } \mathrm{SA}=10.3 \mathrm{~h}^{-1} \times 0.17=1.76 \mathrm{~h}^{-1} \\
\mathrm{~S} / \mathrm{V} & =19,000 \mathrm{~mL} / \mathrm{h} \cdot \text { person } / 43 \mathrm{~m}^{3} / \text { person } \\
& =442 \mathrm{ppm} / \mathrm{h} \\
\Delta \mathrm{C} & =(\mathrm{S} / \mathrm{V}) /(\mathrm{R} / \mathrm{V})=442 / 1.76=251 \mathrm{ppm} \\
\mathrm{C} & =\Delta \mathrm{C}+360=611 \mathrm{ppm}
\end{aligned}
$$

Thus, roughly speaking, the typical expected indoor $\mathrm{CO}_{2}$ level in a commercial building, $610 \mathrm{ppm}$, is about comparable to that in the average home, $670 \mathrm{ppm}$, because, although the average occupant density is 3 times higher ( $43 \mathrm{~m}^{3} /$ person versus $123 \mathrm{~m}^{3} /$ person in a home), the outside air rate is more than 3-times higher (1.76 h-1 versus $0.5 \mathrm{~h}^{-1}$ in a home). It should be mentioned that the high SA rate, $10.3 \mathrm{~h}^{-1}$, is used to assure that temperature and humidity stay within the specified human comfort zone.

These levels $\left(\mathrm{CO}_{2} \approx 650 \mathrm{ppm}\right.$ and $\mathrm{ACH}$ Building $\left.\approx 1.8 \mathrm{~h}^{-1}\right)$ can be compared with the ASHRAE requirement of $10 \mathrm{~L} / \mathrm{s} \cdot$ person. The $\mathrm{CO}_{2}$ concentration equivalent is

$$
\begin{aligned}
\Delta C & =S / R=19 \mathrm{~L} / \mathrm{h} \cdot \text { person } \times 106 /(10 \mathrm{~L} / \mathrm{s} \cdot \text { person } \times 3600)=528 \mathrm{ppm} \\
C & =528+360=890 \mathrm{ppm}
\end{aligned}
$$


It can be shown that the recommended maximum $\mathrm{CO}_{2}$ level of $1000 \mathrm{ppm}(\mathrm{C}=1000-360=$ $640 \mathrm{ppm}$ ) is equivalent to a $\mathrm{CO}_{2}$ rate of $23 \mathrm{~L} / \mathrm{h}$ - person -- about that for an active adult. The equivalent ventilation rate to the ASHRAE value of $10 \mathrm{~L} / \mathrm{s} \cdot$ person $\left(0.010 \mathrm{~m}^{3} / \mathrm{s} \cdot\right.$ person $)$ is $\mathrm{ACH}=0.010 \mathrm{~m}^{3} / \mathrm{s} \cdot$ person $\times 3600 \mathrm{~s} / \mathrm{h} / 43 \mathrm{~m}^{3} /$ person $=0.84 \mathrm{~h}^{-1}$, that is, about half that of the rule-of-thumb value of $1.76 \mathrm{~h}^{-1}$.

Persily and Dols ${ }^{3}$ measured $\mathrm{CO}_{2}$ in three office buildings; peak zonal $\mathrm{CO}_{2}$ levels for the buildings as a whole ranged from 400 to $750 \mathrm{ppm}$, but always below the expected $\mathrm{C}=\mathrm{S} / \mathrm{R}$ values for $43 \mathrm{~m} 3 /$ person. Local $\mathrm{CO}_{2}$ levels ranged from 700 to $950 \mathrm{ppm}$ on one floor in Building $\mathrm{C}$ which had peak zonal levels of 580 to $750 \mathrm{ppm}$.

Shaw et al. ${ }^{4}$ investigated an 8 -story office building which had occupant complaints. Even though $\mathrm{ACH}$ values as low as $0.4 \mathrm{~h}^{-1}$ were measured by $\mathrm{SF}_{6}$ tracer decay, the low occupant density of $168 \mathrm{~m}^{3} /$ person gave an equivalent ASHRAE ventilation rate of $18.6 \mathrm{~L} / \mathrm{s} \cdot$ person (above the guideline) on a total zone or building basis which would give an incremental $\mathrm{CO}_{2}$ of $19 \times 10^{6} / 18.6 \times 3600$ or $\Delta \mathrm{C}=284$ or $\mathrm{C}=360+284+644 \mathrm{ppm} \mathrm{CO}_{2}$. In one test with a measured $\mathrm{ACH}$ of $0.61 \mathrm{~h}^{-1}$ (equivalent to $28.4 \mathrm{~L} / \mathrm{s} \cdot$ person or $\Delta \mathrm{C}_{\mathrm{CO}_{2}}=186$ and $\mathrm{C}_{\mathrm{CO}_{2}}=$ $546 \mathrm{ppm}$ ), the mid-morning and mid-afternoon measured $\mathrm{CO}_{2}$ levels of 500 to $515 \mathrm{ppm}$ were in good agreement with the expected value of $546 \mathrm{ppm}$. Shaw found that when ACH was reduced such that $\mathrm{CO}_{2}$ exceeded $520 \mathrm{ppm}$, the number of occupant complaints increased significantly. These $\mathrm{CO}_{2}$ levels were averages measured over entire floors or return air (RA) ducts; it is likely that local $\mathrm{CO}_{2}$ levels may have been much higher in some locations.

In a recent 1994 test, ${ }^{6}$ a building with IAQ complaints had an occupancy density of $71 \mathrm{~m} 3 /$ person with 70 persons per floor and an average mid-day $\mathrm{CO}_{2}$ level of $680 \mathrm{ppm}$, well below the ASHRAE maximum of $1000 \mathrm{ppm}$. Using these steady-state occupancy and $\mathrm{CO}_{2}$ levels, the estimated ventilation rate was:

$$
\mathrm{R}=\mathrm{S} / \Delta \mathrm{C}=70 \times 19,000 \mathrm{~mL} / \mathrm{h} \cdot \text { person } /(680-360)=4150 \mathrm{~m}^{3} / \mathrm{h}
$$

or

$$
\mathrm{ACH}=4150 / 4975=0.84 \pm 0.08 \mathrm{~h}^{-1}
$$


Based on the decay of $\mathrm{CO}_{2}$ from $730 \mathrm{ppm}$ at $4: 30 \mathrm{pm}$ to about $380 \mathrm{ppm}$ by $7: 30 \mathrm{pm}$, a turnover time $(\tau=1 / \mathrm{ACH})$ of $1.1 \pm 0.15 \mathrm{~h}$ or $\mathrm{ACH}=0.90 \pm 0.12 \mathrm{~h}^{-1}$ was estimated, in agreement with the steady-state-derived value above and equivalent to a ventilation rate of $0.90 \mathrm{~h}^{-1} \times 71 \mathrm{~m}^{3} /$ person $\mathrm{x}$ $1000 \mathrm{~L} / \mathrm{m}^{3} / 3600 \mathrm{~s} / \mathrm{h}$ or $17.8 \mathrm{~L} / \mathrm{s} \cdot$ person.

From these few tests, elsewhere, it appears that perceptions of poor IAQ commenced around $\mathrm{CO}_{2}$ levels of 550 to $700 \mathrm{ppm}-\sim 600 \mathrm{ppm}$, on average. Table 6 below gives expected average zonal $\mathrm{CO}_{2}$ concentrations based on individual ventilation rates, $\mathrm{r}_{\mathrm{p}}$, that is, flow rate per person:

$$
\overline{\Delta C}_{z}=\frac{S_{\mathrm{CO}_{2}}}{3600 r_{p}}
$$

and

$$
\overline{\mathrm{C}}_{2}=360+\overline{\Delta \mathrm{C}}_{\mathrm{z}}
$$

$\mathrm{ACH}$ rates based on individual ventilation rates and occupancy levels are given by:

$$
\mathrm{ACH}=\frac{3.6 \mathrm{r}_{\mathrm{p}}}{v_{\mathrm{p}}}
$$

It appears that to keep $\mathrm{CO}_{2}$ levels below about $700 \mathrm{ppm}$ would require an $\mathrm{r}_{\mathrm{p}}$ of $15 \mathrm{~L} / \mathrm{s} \cdot$ person and closer to $20 \mathrm{~L} / \mathrm{s}$ - person to keep $\mathrm{CO}_{2}$ near 600 ppm. Of course, as given in Eq. 5 , the $\mathrm{CO}_{2}$ level in a particular room is that above plus any incremental local $\mathrm{CO}_{2}$ source from individuals in that particular location.

\begin{tabular}{|c|c|c|c|c|c|}
\hline \multirow{2}{*}{$\begin{array}{l}\text { Ventilation } \\
\text { Rate }\left(r_{p}\right) \text {, } \\
\text { L/s - person }\end{array}$} & \multicolumn{2}{|c|}{$\begin{array}{l}\text { Average Zonal } \\
\mathrm{CO}_{2} \text { Conc., ppm }\end{array}$} & \multicolumn{3}{|c|}{$\begin{array}{c}\text { Building } \mathrm{ACH}\left(\mathrm{h}^{-1}\right) \text { at Various } \\
\text { Occupancies }\left(\mathrm{v}_{\mathrm{p}}\right), \mathrm{m}^{3} / \text { person }\end{array}$} \\
\hline & $\overline{\Delta C}_{\mathrm{Z}}{ }^{\mathrm{I}}$ & $\overline{\mathrm{C}}_{\mathrm{Z}}{ }^{2}$ & 10 & 40 & 120 \\
\hline 5 & 1,056 & 1,416 & 1.8 & 0.45 & 0.15 \\
\hline 10 & 528 & 890 & 3.6 & 0.90 & 0.30 \\
\hline 15 & 352 & 712 & 5.4 & 1.35 & 0.45 \\
\hline 20 & 264 & 624 & 7.2 & 1.80 & 0.60 \\
\hline 25 & 211 & 571 & 9.0 & 2.25 & 0.75 \\
\hline Calculate & $\begin{array}{l}=19 \mathrm{~L} / \\
\text { :q. } 8\end{array}$ & & & & \\
\hline
\end{tabular}

Table 6

Relationship between Ventilation Rate, $\mathrm{CO}_{2}$ Levels, Occupancy Density, and ACH 
Based on a usual occupant density of $40 \mathrm{~m}^{3} /$ person (the middle occupant density column in Table 6), the fresh outside air building ACH should be 1.4 to $1.8 \mathrm{~h}^{-1}--$ a typical value. To provide a higher margin of perceived better IAQ, $25 \mathrm{~L} / \mathrm{s} \cdot$ person would keep the entire zonal $\mathrm{CO}_{2}$ concentration at about $570 \mathrm{ppm}$ with a total $\mathrm{ACH}$ of $2.25 \mathrm{~h}^{-1}$ at $40 \mathrm{~m}^{3} /$ person; this would allow more margin for local incremental $\mathrm{CO}_{2}$ generation or other potential pollutant sources.

\section{Gleeson Hall Estimated $\mathrm{CO}_{2}$ Concentrations}

During the day, the predicted zonal $\mathrm{CO}_{2}$ concentrations from the assumed occupancy levels (based on visual inspection of the offices, laboratories, and classrooms) can be compared with that from a suggested occupancy level of $43 \mathrm{~m}^{3}$ /person. ${ }^{3}$ For the four zones, Table 7 lists the volumes, the suggested and assumed occupancy levels, and the predicted $\mathrm{CO}_{2}$ concentrations based on the suggested and assumed occupancy levels.

\section{Table 7}

Suggested versus Assumed Occupancy and Predicted $\mathrm{CO}_{2}$ Levels

\begin{tabular}{|c|c|c|c|c|c|c|c|c|c|}
\hline \multirow[b]{3}{*}{ Zone } & \multirow[b]{3}{*}{$\mathrm{AH}$} & \multirow{3}{*}{$\begin{array}{c}\mathrm{ACH}, \\
\mathrm{h}^{-1} \\
\end{array}$} & \multirow{3}{*}{$\begin{array}{l}\text { Vol., } \\
\mathrm{m}^{3} \\
\end{array}$} & \multirow{3}{*}{$\begin{array}{c}\text { Suggested } \\
\text { Occupants } 1 \\
\end{array}$} & \multirow{2}{*}{\multicolumn{2}{|c|}{ Assumed Occupants }} & \multicolumn{3}{|c|}{ Zonal $\mathrm{CO}_{2}$ Concentrations, $\mathrm{ppm}$} \\
\hline & & & & & & & Suggested ${ }^{3}$ & \multicolumn{2}{|c|}{ Assumed Occupants } \\
\hline & & & & & Qty. ${ }^{2}$ & $\mathrm{~m}^{3} / \mathrm{per}$ & Occupants & Primary Zone & All Zones \\
\hline 1 & $\mathrm{AC} 2$ & 2.63 & 4,580 & 106 & 77 & 59 & 543 & 454 & 528 \\
\hline 2 & $\mathrm{AC} 3$ & 1.74 & 5,100 & 119 & 120 & 43 & 590 & 551 & 606 \\
\hline 3 & $\mathrm{AC} 4$ & 2.15 & 740 & 17 & 60 & 12 & 560 & 896 & 940 \\
\hline 4 & AC5 & 6.86 & 680 & 16 & 60 & 11 & 446 & 571 & 606 \\
\hline \multicolumn{2}{|c|}{ All Zones } & & 11,100 & 258 & 317 & & & & 581 \\
\hline $\mathbf{1}$ & & & & & & & & & \\
\hline $3 \mathrm{~B}$ & ant & ctur & $\mathrm{H}$ val & . & & & & & \\
\hline
\end{tabular}

For a suggested occupancy of $43 \mathrm{~m}^{3} /$ person, that is, the occupants uniformly distributed in each zone, but using the actual $\mathrm{ACH}$ rates from each zone, the zonal $\mathrm{CO}_{2}$ levels ranged from 543 to $590 \mathrm{ppm}$ in the first three zones and only $446 \mathrm{ppm}$ in Room 294 (AC5) because of the high $\mathrm{ACH}$ rate. It would appear that perceived IAQ would be good at the suggested occupancy desntity -- but this is not how buildings are actually used. 
Based on the assumed occupancy levels listed above and in Table 3, the zonal $\mathrm{CO}_{2}$ concentrations in Table 7 were computed by adding the ambient level ( $360 \mathrm{ppm})$ to each of the $\overline{\Delta \mathrm{C}}_{\mathrm{Z}}^{\mathrm{CO}}{ }_{2}$ in Table 3 under "All Zones"; the primary zone concentration was based on the contribution from occupants in that zone only, that is, 360 plus the maximum value in each zone from Table 3.

For the entire tested portion of the building, the total zonal $\mathrm{CO}_{2}$ level is estimated to be $581 \mathrm{ppm}$ for the assumed occupancy; this level is almost at the $25 \mathrm{~L} / \mathrm{s} \cdot$ person level of $571 \mathrm{ppm}$ in Table 6 and, as such, the perceived IAQ should have been good. As an aside, the total infiltration rate from the appendix $\left(27,212 \mathrm{~m}^{3} / \mathrm{h}\right.$ for 317 assumed occupants) is equivalent to $23.8 \mathrm{~L} / \mathrm{s} \cdot$ person.

Looking at the expected $\mathrm{CO}_{2}$ concentrations by zone, $\mathrm{AC} 2$ has the lowest value, $\mathrm{AC} 3$ and 5 are the same (606 ppm each), and AC4 is quite elevated; the $940 \mathrm{ppm}$ level is generated almost entirely by the AC4 assumed occupancy in combination with the zone's low ACH resulting in a $896 \mathrm{ppm}$ level due to that zone alone, that is, not $\mathrm{CO}_{2}$ contributed from other zonal occupants. Clearly, then, $\mathrm{AC} 4$ is the only zone from a total zonal basis to possibly be inadequately ventilated when a class of 60 students was present.

Returning to Table 4 with the predicted $\mathrm{CO}_{2}$ levels computed in the 13 rooms tested with the surrogate PFT source, only the estimated levels (under the column labeled $C_{R}$ ) in rooms handled by AC2 have values less than $600 \mathrm{ppm}$. Room 444A with $1 \mathrm{SA}$ grill generated $55 \mathrm{ppm}$ $\mathrm{CO}_{2}$ locally ( $\Delta \mathrm{C}_{\text {local }}$ ), giving a room concentration of $583 \mathrm{ppm}$; the occupant had complained of inadequate fresh air but this was not the case during this test. Room 444 with 4 SA grills was not tested (there were complaints here as well) but it is not likely to have had inadequate ventilation either.

The only tested room running on $\mathrm{AC} 2$ to have an elevated predicted $\mathrm{CO}_{2}$ was Room 342 . This somewhat larger classroom had only 2 SA grills which did not, at that time, appear to be working (physical inspection) and, indeed, the room had a stuffy feeling. Based on the number of student desks in the room, an estimated occupancy of 8 adults would have generated a room 
concentration of $706 \mathrm{ppm}$-- above the cutoff value suggested in this paper of $600 \mathrm{ppm}$. The high locally-generated $\mathrm{CO}_{2}$ of $178 \mathrm{ppm}$ from the 8 adults resulted from the locally poor SA rate per grill $\left(430 \mathrm{~m}^{3} / \mathrm{h}\right)$.

The incremental room $\mathrm{CO}_{2}$ concentration per person, $\Delta \mathrm{C}_{\mathrm{R}} /$ person, of $25 \mathrm{ppm}$ per person was about the same for the two third floor rooms in Table 4. Thus, the Room 342 high $\mathrm{CO}_{2}$ concentration was related to the larger number of people in that room. On the other hand, the low $\Delta C_{R} /$ person determined for Rooms $208 \mathrm{~A}$ and $208 \mathrm{C}$ guarantees that those rooms, as operated, could handle their greater occupancy density without reaching a critical $\mathrm{CO}_{2}$ level. Peculiarly, these teaching dental laboratories had also had air quality complaints. But there is no question that the local ventilation was high, so neither a large number of occupants nor any other pollutant source (such as chemicals used in the lab) should have caused an IAQ problem.

The two rooms tested on the fourth floor controlled by AC3 were large multi-occupancy office areas with moderately low incremental $\mathrm{CO}_{2}$ concentrations per person with high apparent ventilation rates per grill. The room $\mathrm{CO}_{2}$ concentrations of $670 \mathrm{ppm}$ were low enough to expect a reasonably good perceived IAQ status. On the other hand, one floor down, Rooms 323 and 339 , used as classrooms, had high room $\mathrm{CO}_{2}$ concentrations, $948 \mathrm{ppm}$, because of low ventilation rates per grill, and modestly high incremental $\mathrm{CO}_{2}$ concentrations per person of 19 and $25 \mathrm{ppm} /$ person, respectively. On the second floor, Room 209B, a laboratory in the $\mathrm{x}$-ray suite, had the lowest ventilation rate per grill and one of the highest incremental $\mathrm{CO}_{2}$ rates per person. Only the low estimated number of occupants, 2 , kept the predicted $\mathrm{CO}_{2}$ level near $700 \mathrm{ppm}$; each additional person would have raised the $\mathrm{CO}_{2}$ by $51 \mathrm{ppm}$. Finally, classroom 213 , with about 15 desks, had a high predicted $\mathrm{CO}_{2}$ concentration (902 ppm) with a high $\mathrm{CO}_{2}$ level per person (32 ppm/person). Thus, this room could have had a potentially poor IAQ.

The last two $\mathrm{AH}$ systems each handled their own individual rooms -- AC4 ran Lecture Room 202 only, and AC5, Lecture Room 204. AC5, with its high ACH rate $\left(6.86 \mathrm{~h}^{-1}\right)$, was operating at a level to keep the $\mathrm{CO}_{2}$ concentration from 60 people at about $700 \mathrm{ppm}$ or less -probably good perceived IAQ. AC4, on the other hand, at a rate of $2.15 \mathrm{~h}^{-1}$, would have had the highest $\mathrm{CO}_{2}$ levels -- over 1000 ppm. 


\section{Mitigating Strategies}

Both energy conservation and perceived and actual IAQ and occupant comfort are important issues in any building. These PFT test results indicate that there was both a need to reduce $\mathrm{ACH}$ during low-occupancy periods to conserve energy and, during the expected normaloccupancy periods, a need to improve both zonal ACH and local ventilation and, possibly, alter room assignment.

Energy conservation measures could be easily accommodated in two time periods. As pointed out earlier in the Discussions, a modest uniform ACH rate of $1.5 \mathrm{~h}^{-1}$ in all zones early in the morning, for example, from 6:00 to 8:00 am weekdays, would have provided about a $25 \%$ energy savings relative to the $2.5-\mathrm{h}^{-1}$ rate, a level which has been shown to be more than adequate for good perceived IAQ at normal ( $40 \mathrm{~m}^{3} /$ person) occupant densities (cf., Table 6). Furthermore, late at night and on weekends, a roll-back to $0.5 \mathrm{~h}^{-1}$ would certainly provide sufficient fresh air to the few occupants that might be present and would reduce energy consumption by $50 \%$; a modest temperature set-back (in the winter) would provide an additional $10 \%$ savings.

Perceived indoor air quality improvement requires consideration of the total zonal occupant burden and the individual rooms' occupant levels and supply air (SA) availability. As was pointed out in Table 7 , based on the assumed occupancy levels on a total zonal basis, three of the four zones had sufficient overall fresh air; AC2 was perfect (only 528 ppm of $\mathrm{CO}_{2}$ predicted) and AC3 and AC5 could have benefitted from slightly higher ventilation rates. However, AC4, assuming 60 student present in the lecture room, should have had a much higher outside air $\mathrm{ACH}$ rate.

If the total occupancy level was the same as assumed in Table 3, it could be shown that the following adjustments to total zonal ventilation would reduce the incremental zonal $\mathrm{CO}_{2}$ levels to about $160 \mathrm{ppm}$ in each zone during the daytime occupied periods: 


\begin{tabular}{llll} 
& \multicolumn{2}{c}{$\mathrm{ACH}, \mathrm{h}^{-1}$} \\
$\mathrm{AH}$ & Before & After \\
$\mathrm{AC} 2$ & 2.63 & & 2.6 \\
$\mathrm{AC} 3$ & 1.74 & & 2.7 \\
$\mathrm{AC} 4$ & 2.15 & & 9 \\
$\mathrm{AC} 5$ & 6.86 & & 9.5
\end{tabular}

The remaining steps to be taken require examining the local $\mathrm{CO}_{2}$ response and the number

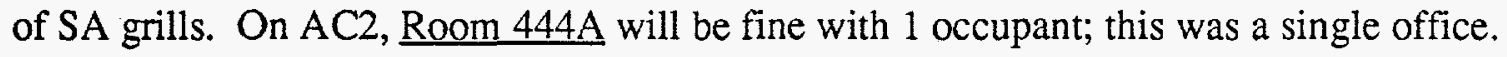
Room 341, a secretarial area, would be acceptable with 2 or 3 occupants. Room 342, a classroom with only 2 grills working at poor capacity, requires correcting the SA setting and adding at least 1 (preferably 2) new SA grills; this would reduce the incremental $\mathrm{CO}_{2}$

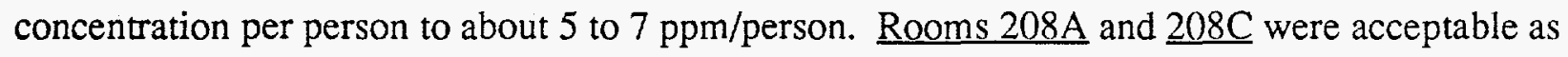
is.

After adjustment of AC3 from 1.7 to $2.7 \mathrm{~h}^{-1}$ during daytime occupancy, three of the 6 rooms tested in that zone would need further individual adjustment. Classroom 323 had a sufficient number of SA grills (4) for its small size, but to support an estimated 20 students, the local fresh air rate from each needed to be tripled. Classroom 339 with only 3 SA grills had a higher incremental $\mathrm{CO}_{2}$ value (25 ppm/person compared to $19 \mathrm{ppm} /$ person for Room 323). Thus, both an additional SA grill was needed and the rate from each needed to be increased 2.5fold; with these changes, both rooms 323 and 339 would have had $\mathrm{CO}_{2}$ levels at about $600 \mathrm{ppm}$. Lastly, the small Room 213 either needed to be re-assigned as a 1-or, at most, 2-person office or an extra SA grill installed and the delivery rate increased 2.5 -fold.

Rooms 202 and 204 would be fine for 60 occupants each with just the increase in total outside air $\mathrm{ACH}$ to $9 \mathrm{~h}^{-1}$. 


\section{$\underline{\text { Recommendations }}$}

Now that the reconstruction work on Gleeson Hall has been completed, retesting should be done to compare the ventilation rate and the predicted $\mathrm{CO}_{2}$ levels. In addition to the testing that was performed 2 years ago, the ventilation rate of the perimeter rooms should be checked and more rooms, if not all rooms, on the AH systems should be tagged with the surrogate PFT source to check all local ventilation rates. Where possible, local $\mathrm{CO}_{2}$ measurements should be made to confirm the reliability of the prediction capabilties of this technology.

The techniques employed in these tests and the results should be critically reviewed by the college staff for their assessment of the utility of the approach, in part to determine if the technology should be made more widely available and, in part, to set up student participation in the advancement of the implementation and interpretation of the PFT technology as a ventilation engineer's tool.

\section{CONCLUSIONS}

As a result of performing two several-day BNL-AIMS passive device ventilation tests, both the zonal and local ventilation performance of a significant portion of the Gleeson Hall building was satisfactorily performed. The ventilation rates determined for the four operating air handling $(\mathrm{AH})$ systems, $\mathrm{AC} 2$ to $\mathrm{AC5}$, were identical in both tests and ranged from about 1.5 to $6.8 \mathrm{~h}^{-1}$.

In the second test, the use of a distributed PFT source as a surrogate for occupants who normally expire $\mathrm{CO}_{2}$ was able to quantify the effectiveness of local (individual rooms) ventilation in combination with total zonal ventilation to arrive at a reliable predicted $\mathrm{CO}_{2}$ concentration in each location tested (13 rooms); $\mathrm{CO}_{2}$ concentrations were predicted to range from 536 to $1003 \mathrm{ppm}$.

A review of some published building ventilation studies during which $\mathrm{CO}_{2}$ measurements and perceived air quality were noted plus some private communications and assessment of ASHRAE guidelines resulted in the observation that indoor $\mathrm{CO}_{2}$ concentrations from occupants should, in general, be less than $600 \mathrm{ppm}$ to assure a good perceived IAQ and that to achieve these 
desired conditions over an entire zone serviced by a given AH system, would require a fresh air ventilation rate of 20 to $25 \mathrm{~L} / \mathrm{s} \cdot$ person which, at an occupancy level of $40 \mathrm{~m}^{3} /$ person, is equivalent to an $\mathrm{ACH}$ rate of 1.8 to $2.2 \mathrm{~h}^{-1}$.

During these two tests in Gleeson Hall, the $\mathrm{ACH}$ rates were constant and identical for Test 1 over a 2-day weekday period and for Test 2 over a 3 -day weekend period. From an IAQ (indoor air quality) standpoint, it was determined that during the day, based on the assumed occupancy, AC2 was running at the right rate $\left(2.6 \mathrm{~h}^{-1}\right), \mathrm{AC} 3$ needed to be increased from 1.7 to $2.7 \mathrm{~h}^{-1}$, and ACs 4 and 5 from 2.2 and $6.8 \mathrm{~h}^{-1}$, respectively, to about $9 \mathrm{~h}^{-1}$. However, at night and on weekends, from an energy conservation perspective, all four $\mathrm{AH}$ systems should be reduced to $0.5 \mathrm{~h}^{-1}$ and the temperature set-back as well (in the winter time) for an estimated $60 \%$ energy savings during the five 8-h periods during the week and two 24 -h periods on the weekend (equivalent to a weekly energy savings of about $30 \%$ ).

Locally poor ventilation, that is, not associated with the AH system as a whole, was identified as significant in 4 of 11 rooms tested -- 1 of 5 tested, running on AC2, and 3 of 6 tested running on AC3. Improvement in local ventilation required that 3 of the 4 add 1 or 2 extra supply air (SA) grills and increase the fresh air rate from each by 2 - to 3 -fold; the fourth room required the SA rate to be tripled.

\section{ACKNOWLEDGMENTS}

Thanks are extended to Jay Fraser of Integrated Innovation for arranging for the testing at the SUNY Farmingdale campus and for assistance in the field implementation, to John Tiedeman, a professor in the HVAC engineering department, for helpful discussions, and to Randy Schnittger, the buildings HVAC operator, for access to locked areas in the building and for suggestions on access points in the AH ductwork for source deployment. Thanks also go to DOE OHER for their fundamental support of the PFT technology at Brookhaven and to DOE ER Laboratory Technology Transfer Program for support in writing the report for this technology demonstration. 
$-22-$ 


\section{REFERENCES}

1. Dietz, R. N., Goodrich, R. W., Cote, E. A., and Wieser, R. F. Detailed description and performance of a passive perfluorocarbon tracer system for building ventilation and air exchange measurements. In Measured Air Leakage of Buildings, ASTM STP 904, H. R. Trechsel and P. L. Lagus, Eds., pp. 203-264, American Society for Testing and Materials, Philadelphia, 1986.

2. D'Ottavio, T. W., Senum, G. I., and Dietz, R. N. Error analysis techniques for perfluorocarbon tracer derived multizone ventilation rates. Building and Environ. $\underline{23}$ (3), 187-194 (1988).

3. Persily, A. and Dols, W. S. The relation of $\mathrm{CO}_{2}$ concentration to office building ventilation. In Air Change Rate and Airtightness in Buildings, ASTM STP 1067, M. H. Sherman, Ed., pp. 77-92, American Society for Testing and Materials, Philadelphia, 1990.

4. Shaw, C. Y., Magee, R. J., Shirtliffe, C. J., and Unligil, H. Indoor air quality assessment in an office-library building: Part II - Test results. ASHRAE Tech. Data Bull. I (4), 8-17 (1991).

5. Ventilation for acceptable indoor air quality. ASHRAE Standard 62-1981R, American Society of Heating, Refrigeration, and Air Conditioning Engineers, Inc., 1986.

6. Prezant Associates, Inc., private communication, 1994. 



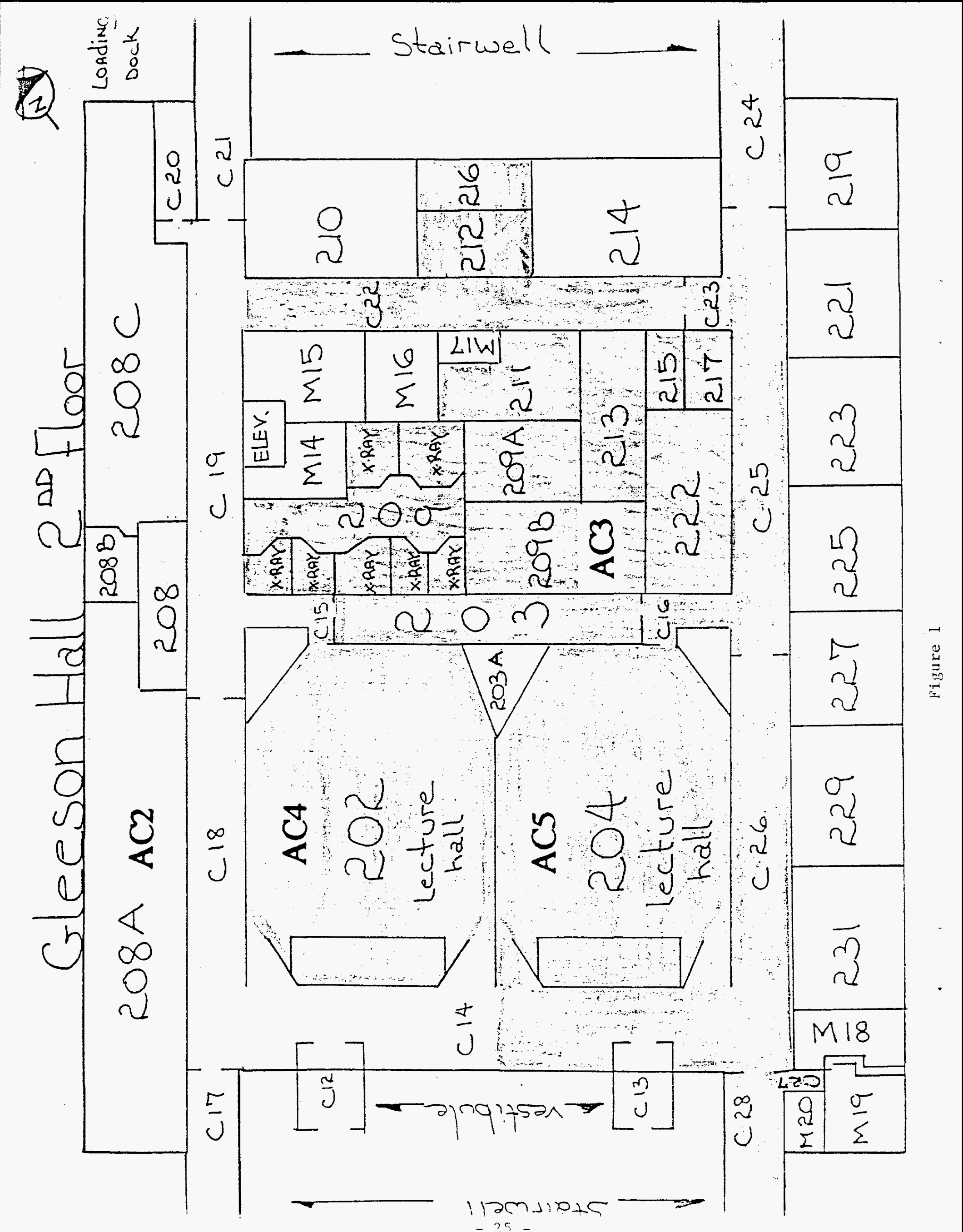




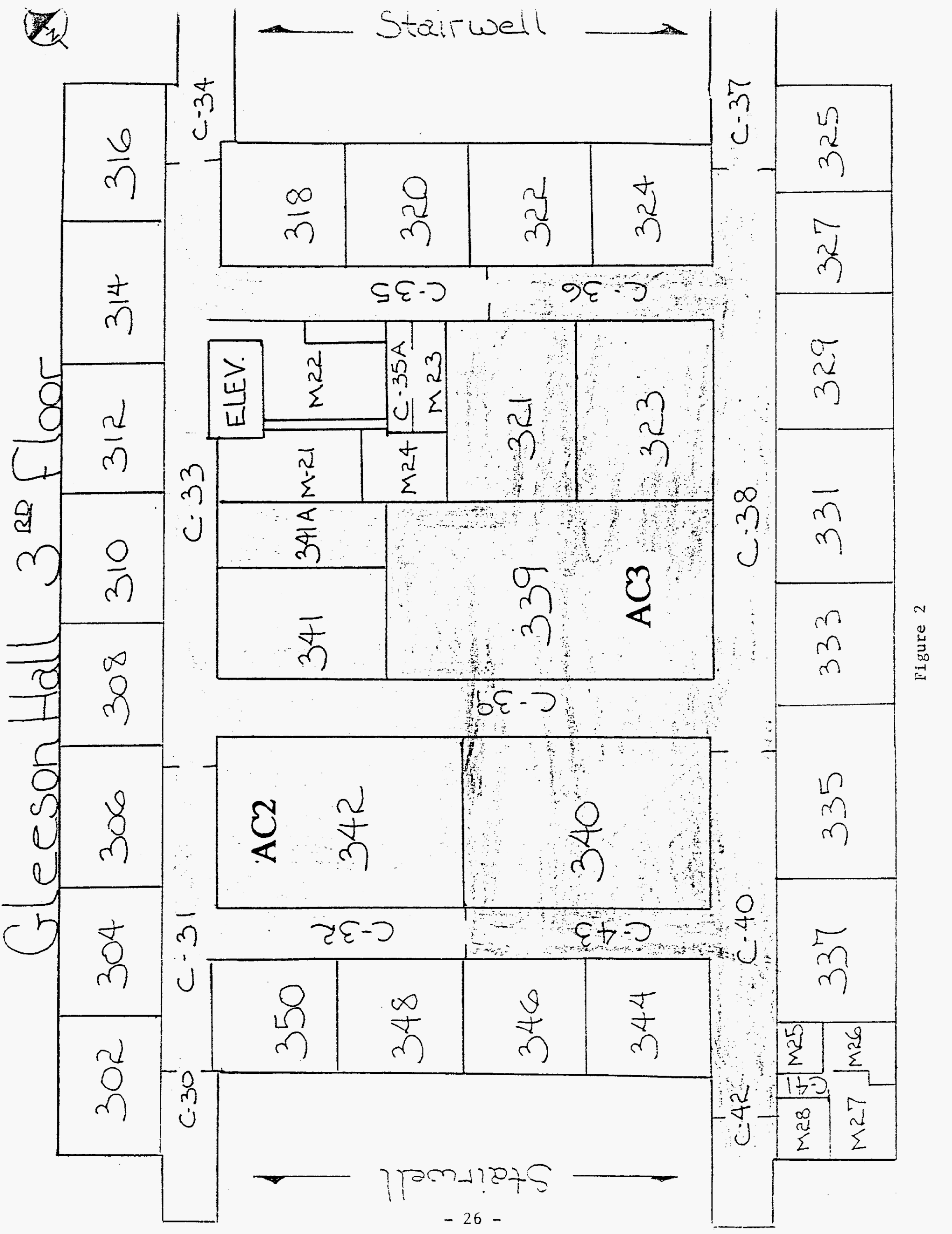




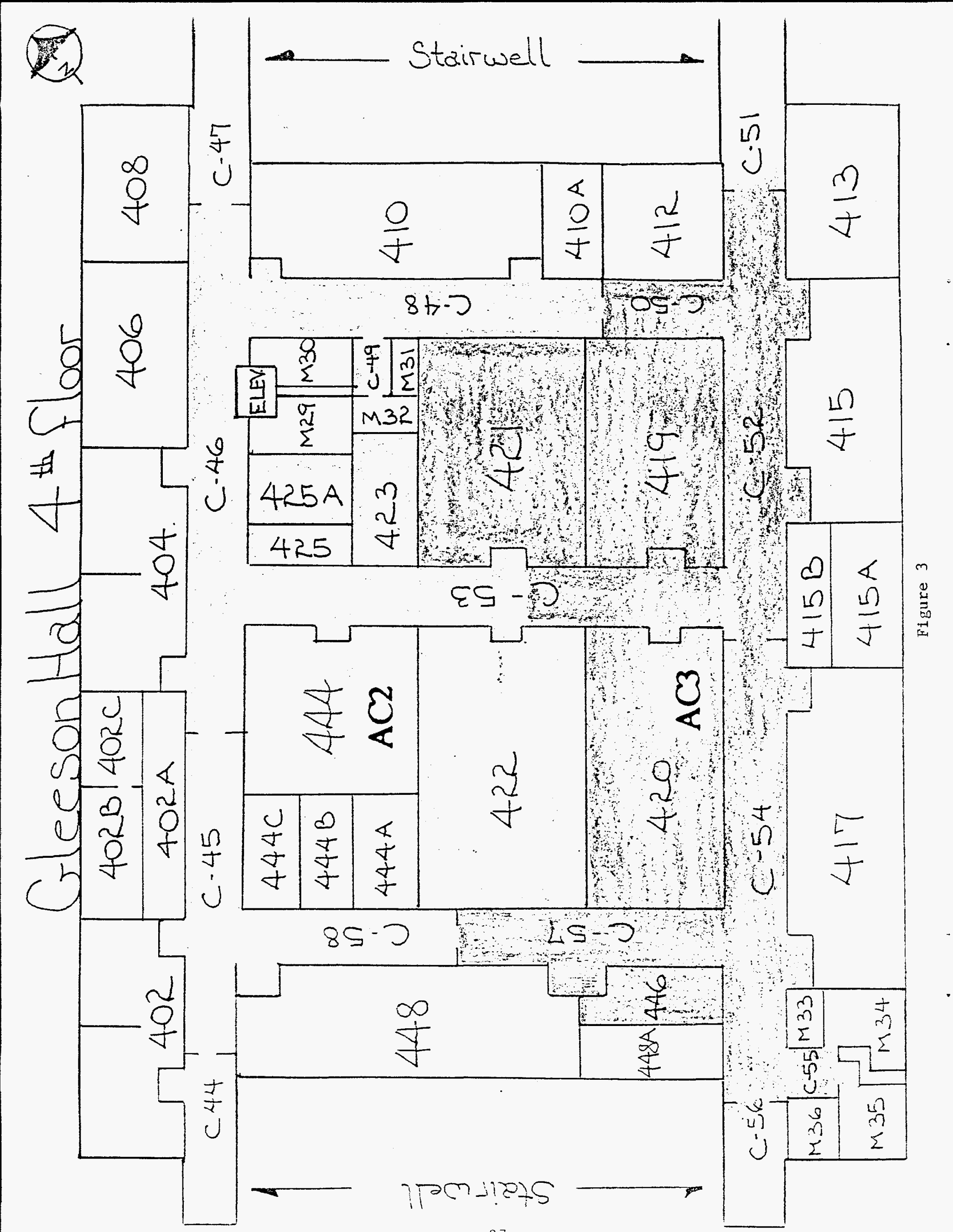


APPENDIX A

Detailed BNL-AIMS Test Reports 
BNR-AIMS

PROJECT, SUNY FARMINGDAL HOUSE \& GLEESON HALL
START: 12,40 (04-07-1993) Wed

STOP: $10: 00(04-09-1993) F_{L i}$
$08: 51: 50 \quad 05-07-1993$

BNL CODE: BO20AO

ANALYZED: 03-31-1993

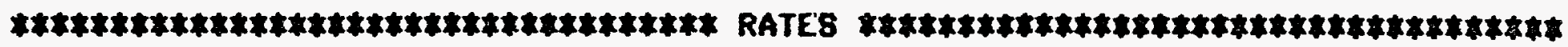

OVERALL INFILTRATION RATE $=27186.7 \pm 2126.4\left(\mathrm{n}^{\wedge} \mathrm{3} / \mathrm{h}\right)$

OUERALL AIR EXCHANGE RATE $=1.409 \pm 0.117(1 / \mathrm{h})$

2

O ZONE

SOURCE RATE

N LOCATION

E

1 1ST FLOOR

2 AC2

3 AC3

4 AC4

5 AC5

$\begin{array}{rr}\text { e25C } & \text { QT } \\ \text { (nL/E) } & \\ 6.9 & 14 \\ 35.7 & 3 \\ 25.3 & 5 \\ 8.8 & 3 \\ 5.2 & 6\end{array}$
RATE

(nL/h)

5088

$\$ 773$

6667

1389

1541

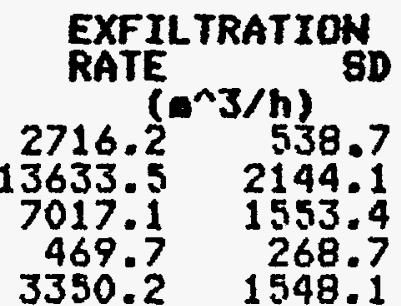

8D
ZONE-ZONE

$1=2$
$1=\frac{2}{3}$

$1-4$

$1-5$

$2-3$

$2-4$

2
$3-5$

$3-5$

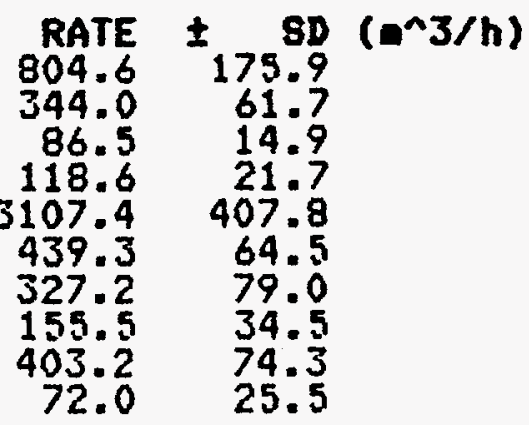

ZONE RATE \pm SD $\left(\mathrm{N}^{-3} / \mathrm{h}\right)$ ACH $\pm \mathrm{SD}(\mathrm{h})$

$14069.8 \quad 639.3$

$\begin{array}{rrr}3 & 12198.0 & 1297.0 \\ 5 & 4756.4 & 593.9\end{array}$

0.496

2.382

6.995

0.082

0.279

0.941

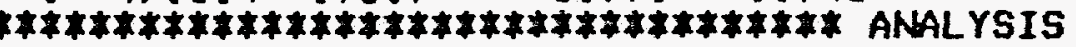

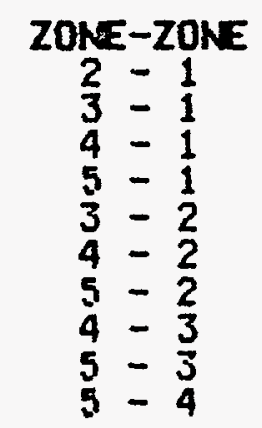

:-DATE-INFILTRATION

RATE

$\left.1854 .{ }^{\wedge} 3 / h\right) 330.4$

$12403.6 \quad 2315.7$

$7626.3 \quad 869.2$

$1467.0 \quad 161.2$

482.4

$\begin{array}{ll}\text { ACH } & \text { SD } \\ \text { (/h) } & \\ 0.226 & 0.042 \\ 2.708 & 0.523 \\ 1.495 & 0.186 \\ 1.982 & 0.239 \\ 5.640 & 0.763\end{array}$

$\begin{array}{rr}\text { RATE } & \pm \text { SD (a^3/h) } \\ 837.4 & 170.5 \\ 591.7 & 150.2 \\ 607.2 & 128.4 \\ 179.3 & 131.8 \\ 3980.5 & 1213.5 \\ 577.9 & 164.6 \\ 578.2 & 1948.6 \\ 383.0 & 62.0 \\ 687.3 & 350.2 \\ -38.5 & 46.9\end{array}$

IN OR OUT- RATE \pm SD $\left(a^{n} 3 / h\right)$ ACH $\pm S D(/ h)$

$218344.8 \quad 2319.4$

$2109.8 \quad 219.6$
4.005

2.851
0.545

0.329
7 Iot saurce

1 Irre

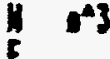

18260 ocpsCs

24580 PMCP

33100 PICH

1740 (P) CY

5680 T-PICH octa

$1.286 \pm 0.151$

$0.073 \pm 0.006$

$0.060 \pm 1.042$

$0.672 \pm 0.003$

$0.043 \pm 0.001$
$0.091 \pm 1.006$

$0.343 \pm 1.624$

$0.095 \pm 1.001$

$0.082 \pm 1.004$

$0.035 \pm 1.004$

AIG.TRACER

con.

Pra

$0.129 ! 0.014$

$0.139 \div 0.433$

$0.394 \div 0.017$

$0.171 \div 0.003$

$0.064 \div 0.045$ tpra

$0.113 \pm 1.014$

$0.034 \pm 0.193$

$0.034 \div 0.092$

$1.672 \div 1.019$

$1.018 \div 1.03$
TPTC

$0.121 \pm 0.007$

$0.016 \pm 0.034$

$0.123 \div 0.002$

$1.000 \pm 1.000$

$1.320 \pm 1.024$ 


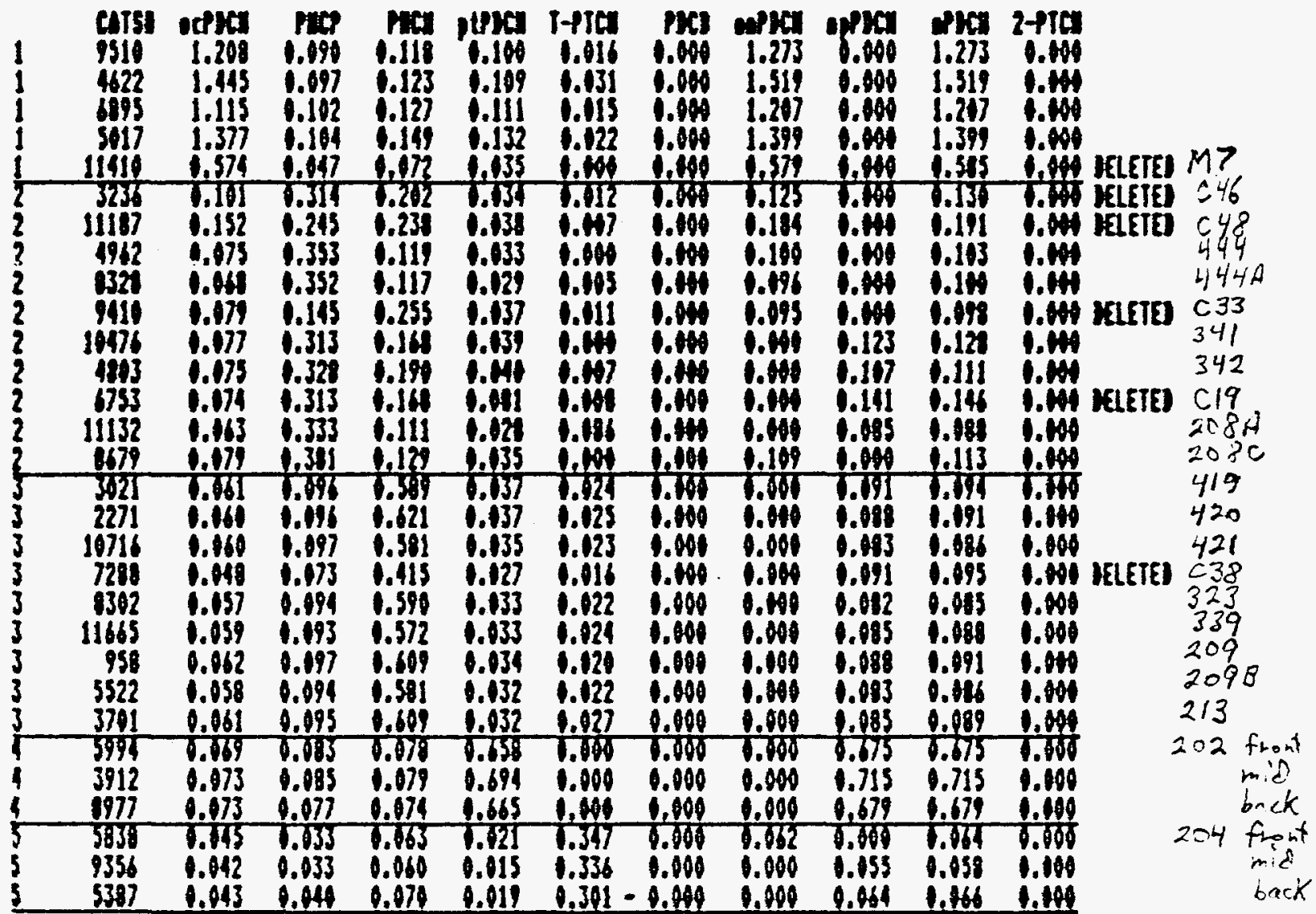

C.F.I PICI PMCP PHCH sCPICH PLPICH APICH PICH COEFFICIENTS FILE

$\begin{array}{llllllll}0.94 & 0.91 & 0.92 & 1.95 & 0.92 & 0.65 & 1.93 & 63160\end{array}$

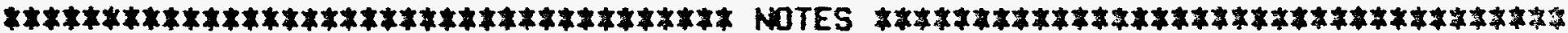

All gas volumes are reported at $25 \mathrm{C}$. and 1 ata.

The standard deviation in the source strength has been set at $10 \%$

The standard deviation in the volume measurement has been set at $5 \%$

The overall normalized condition number $\left(K(C) / N^{\wedge} 1.5\right)=0.502$

$K(D C) / N=1.122$

Zonal condition numbers are:

$\begin{array}{llllll}\text { ZONE } & & 1 & & 3 & 4 \\ \text { Condition Number } & 1.078 & 1.239 & 1.191 & 1.065 & 1.024\end{array}$

FLOW-RATIOS STD.DEV.

INFII,TRN/EXF ILTRN

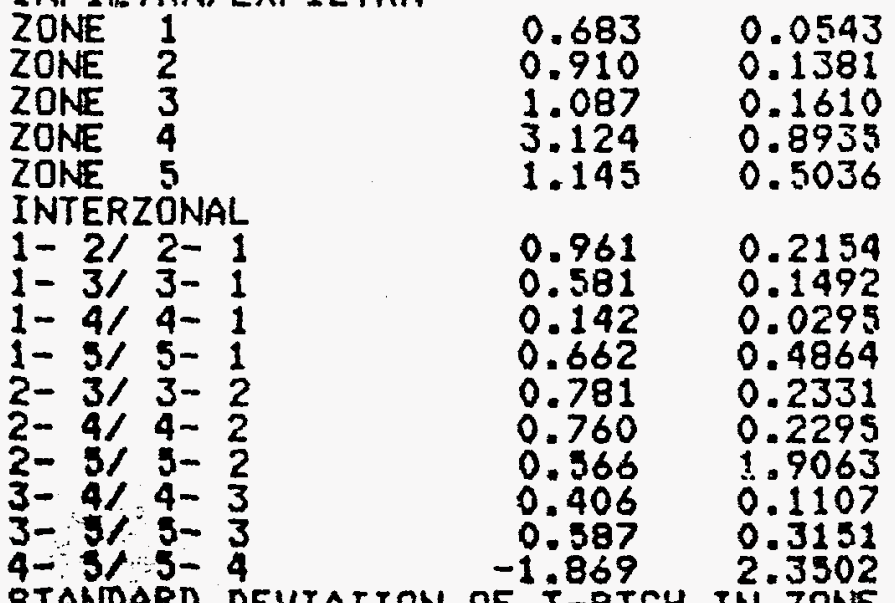

8TANDARD DEVIATION DF T-PTCH IN ZONE 1 IS GREATER THAN $25 \%$

STANDARD DEVIATION OF T-PTCH IN ZONE 2 IS GREATER THAN $25 \%$ 
PROJECT, SUNYFARMINGDALE START: $10: 15$ (04-09-1993) Fi BNL CODE, 8021AO HOUSE : GLEESON HALL STOP: $10: 50(04-12-1993)$ HOW ANALYZED: 04-01-1993

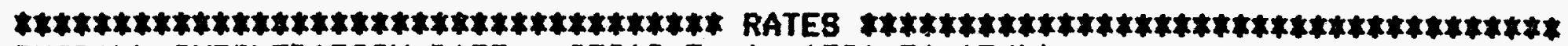
QVERALL INFILTRATION RATE $=27212.3 \pm 1751.7\left(\mathrm{~m}^{\wedge} 3 / \mathrm{h}\right)$ OUERALL AIR EXCHANGE RATE $=2.452 \pm 0.175(1 / \mathrm{h})$ Z

D ZONE SOURCE RATE

N LOCATION O25C QTY ET

E

1 AC2

2 AC 3

3 AC4

4 AC5
EXFILTRATION (nL/h)

35.735773

$25.3 \$ 6667$

8.8331389

5.2661541
RATE SD

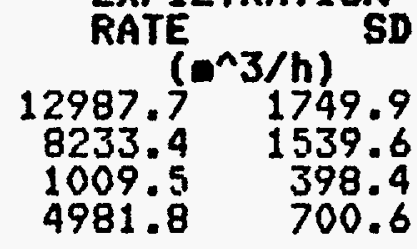

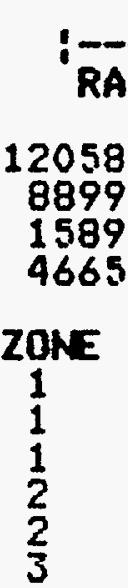

INFILTRATION $\begin{array}{llll} & & \\ \left(\mathrm{An}^{\wedge} 3 / \mathrm{h}\right) & \text { SD } & \text { ACH } & \text { SD } \\ .0 & 1451.9 & 2.633 & 0.343 \\ .7 & 976.0 & 1.745 & 0.210 \\ .3 & 171.6 & 2.148 & 0.256 \\ .3 & 609.4 & 6.861 & 0.960\end{array}$ \begin{tabular}{lrrr} 
& SD & ACH & SD \\
$(\mathrm{A} 3 / h)$ & \multicolumn{2}{c}{$(/ h)$} & \\
.0 & 1451.9 & 2.633 & 0.343 \\
.7 & 976.0 & 1.745 & 0.210 \\
.3 & 171.6 & 2.148 & 0.256 \\
.3 & 609.4 & 6.861 & 0.960
\end{tabular} \begin{tabular}{lrrr} 
& SD & ACH & SD \\
$(\mathrm{A} 3 / h)$ & \multicolumn{2}{c}{$(/ h)$} & \\
.0 & 1451.9 & 2.633 & 0.343 \\
.7 & 976.0 & 1.745 & 0.210 \\
.3 & 171.6 & 2.148 & 0.256 \\
.3 & 609.4 & 6.861 & 0.960
\end{tabular}

$$
\begin{array}{rl}
\text { RATE } & \pm \text { SD }\left(a^{\wedge} 3 / h\right) \\
3945.3 & 983.5 \\
678.6 & 418.6 \\
-75.7 & 164.7 \\
384.8 & 93.5 \\
505.5 & 110.5 \\
23.2 & 28.0
\end{array}
$$

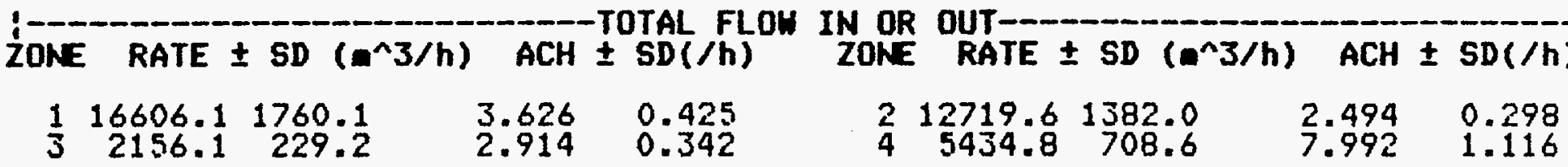

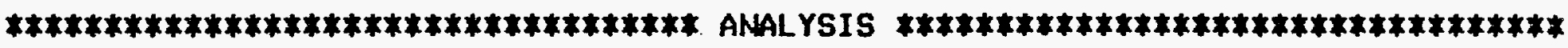

\begin{tabular}{|c|c|c|c|c|}
\hline WH SOURCE & & & & CCER \\
\hline $\begin{array}{l}4580 \text { PNCP } \\
5100 \text { PHCH } \\
740 \text { tPBCH } \\
680 \text {-PICH }\end{array}$ & $\begin{array}{cc}\text { PuCP } \\
0.372 \pm 0.011 \\
0.089 & 0.002 \\
0.075 & 0.001 \\
0.028 \pm 0.002\end{array}$ & 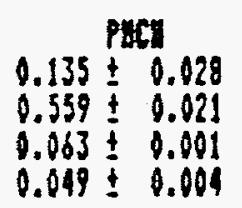 & 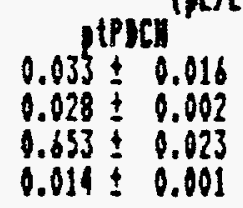 & $\begin{array}{c}=1+10 \\
0.002 \pm 8.003 \\
6.912 \pm 9.062 \\
0.004 \pm 8.004 \\
0.285 \pm 0.024\end{array}$ \\
\hline
\end{tabular}




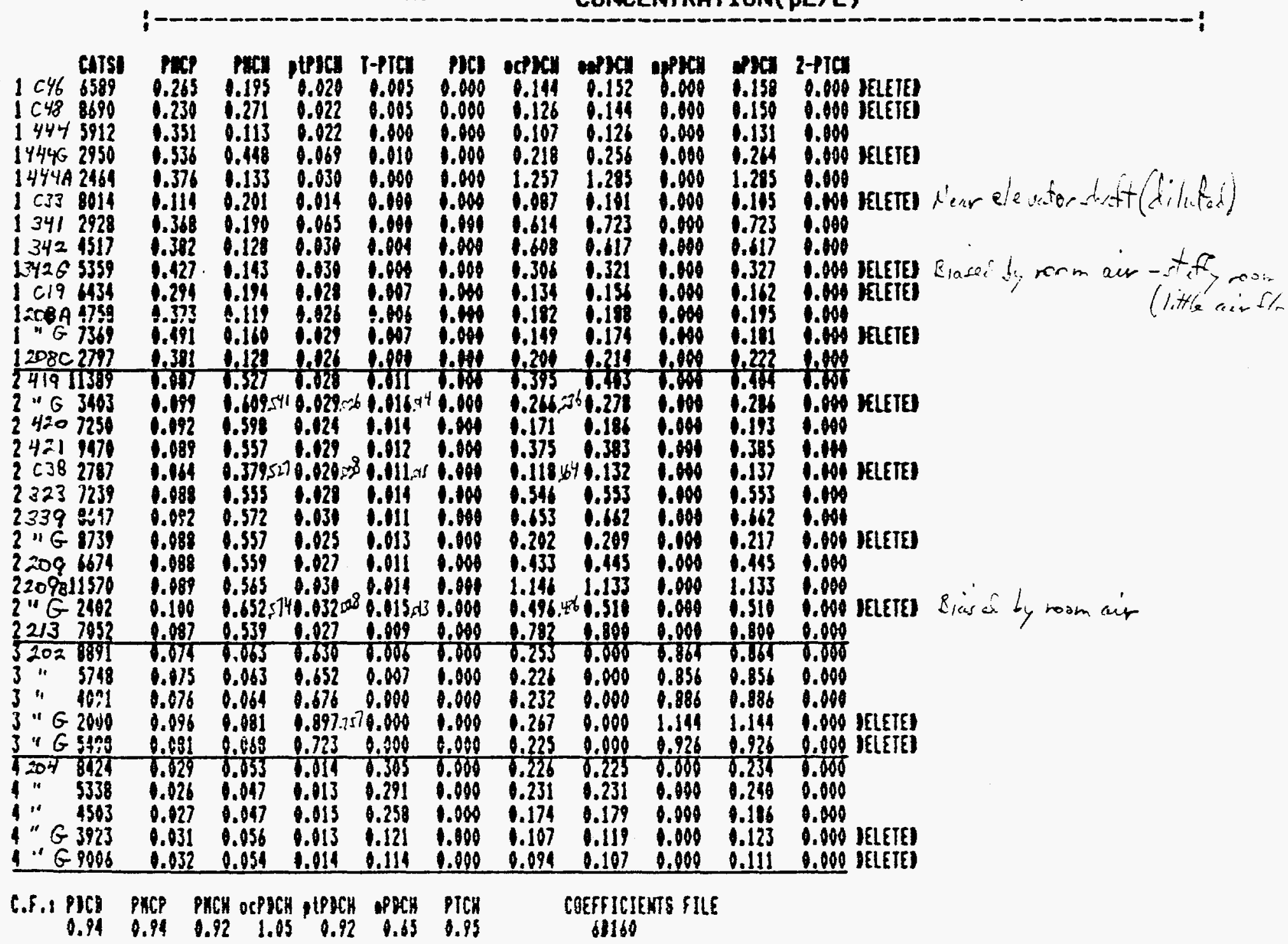

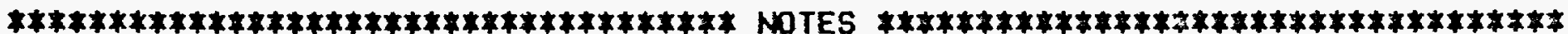

All gas volumes are reported at $25 \mathrm{C}$. and 1 atm.

The standard deviation in the source strength has been set at $10 \%$

The standard deviatirn in the volume measurement has been set at $5 \%$

The overall normalized condition number $\left(K(C) / N^{\wedge} 1.5\right)=0.543$

$K(D C) / N=1.086$

Zonal condition numbers are:

$\begin{array}{lcccc}\text { ZONE } & & & & \\ \text { Condition Number } & 1.155 & 1.138 & 1.035 & 1.009\end{array}$

FLOW-RATIOS STD.DEV.

INF ILTRN/EXF ILTRN

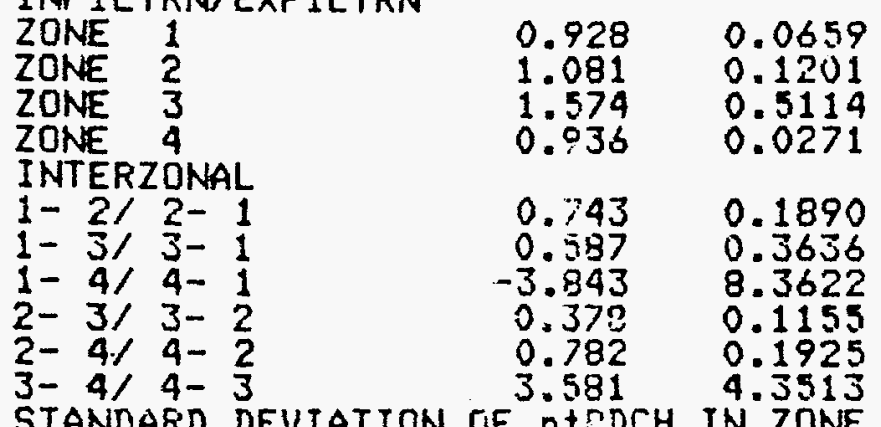

STANDARD DEVIATION OF PTRDCH IN ZONE 1 IS GREATER THAN 2:

STANDARD DEVIATION OF F-FTCA IN ZONE 